\title{
An Assessment of the Library Application Software Packages in Selected Academic Libraries In Nigeria
}

\section{BY}

\author{
ADUBIKA THOMAS.O \\ College Library Yaba College Of Technology Yaba-Lagos \\ solaadubi@yahoo.co.uk
}

\begin{abstract}
The study was conducted to evaluate the library application software packages in use in six (6) academic libraries in Nigeria. Using a 53 item structured questionnaire, the study examined the adopted softwares' security, compatibility/capabilities, user-friendliness, indexing and searching abilities and other such features considered necessary in the assessment of the effectiveness of an ideal library application software package. The study found that most application packages available in the Nigerian automation market place are effective since they are usually packages that have been fully tested, thoroughly de-bugged and well supported by vendors.
\end{abstract}

\section{Introduction}

As the central focus of any educational enterprise, the content and services of the library should be focused on the programmes offered by the institution and also on the needs of the Faculty and Students. In other words, the mission of the academic library should be to acquire information, organize it, preserve it and disseminate an up-todate research collection and information services that meet the immediate and remote needs of its clientele.

Over the years, academic libraries have devised and adopted processes, procedures and schemes that facilitate the active and effective exploitation of its resources. Most of the initial processes and procedures of information dissemination were manually operated. This involves the use of hand and human brain in the performance of library duties. Rowley (1999) however observes that the traditional File-based systems were found to be inadequate particularly for generating high-level planning and controlling information which relate to the whole organization. The generation of effective information requires organizations data to be viewed as a single unit and not as a set of independent units stored in separate files.

As a consequence of the series of researches and developmental activities going on in the global academic community, new information are being generated daily and added to the repertoire of global academic records. It therefore behoves the library not only to seek and bring information together in various sources and in diverse forms, but also to communicate and facilitate access to the knowledge contained there-in to those who need them. Aiyedogbon (1997) noted that the changes taking place in the world, especially information explosion, have continued to affect the pattern of library service. She attributed the increase in the number of people engaged in research and teaching to the expansion of higher education facilities.

With the astronomic rise in students enrolment coupled with the exponential growth in the collection of academic libraries, the manual processes of information handling were found to be slow, tedious and therefore grossly inadequate to meet the ever increasing needs and demands of library patrons who need accurate, timely and adequate information from diverse sources. Hence the need to automate the operations of the library.

Library automation can be defined simply as the use of computers and network technologies in the library. Bierman (1980) sees it as the use of computer and associated technology to do exactly what has been done in the library with the Justifications of reduced cost and or increased performance. That is, it is the use of computers to perform library operations most especially services that are routine and repetitive. 
Meghabghab (1997) asserts that every library, regardless of the type, size and collection, can benefit from automation in that it improves library services and increases productivity, efficiency and accuracy in performing a variety of library operations. Mohammed (1991) opines that Automation of libraries and information systems have today become an acceptable norm being the most realistic ways and means of providing timely, accurate as well as effective means of information management. He posited further that the present age of information and publication explosion in different forms and formats have made it difficult for academic and indeed other types of libraries to perform their roles of facilitating easy access and retrieval of information resources and service without automation.

Library application softwares are programs written individually to operate specific, tailor-made procedures and systems such as library house keeping, words processing, database management, text retrieval, expert systems e.t.c In other words, they are sequence of instructions which will tell the computer what to do, how to manipulate data and how to relate to users. They address one aspect of computing need or the other. An ideal application package should amongst a host of other capabilities, have the ability to store and manipulate data, input information in the data so created and edit data thereby allowing for immediate correction of errors or correction at a later date.

Evaluation basically involves obtaining feedback about how a person or an organization achieves it $\mathrm{s}$ goals and objectives. In general terms, the process serves as an auditing and control function generating information upon which certain personal and organizational decisions are made. Baker and Lancaster (1991) identified three levels of performance evaluation in an automated environment. These are: effectiveness, cost effectiveness and cost benefit analysis. According to them, effectiveness can be measured in terms of how well a service satisfies the demand placed on it by its users. It can also measure output relative to objectives and targets. Cost effectiveness is concerned with a system's internal operating efficiency. For example, to measure how efficiently cost-wise the system is satisfying its objectives. Cost-benefit analysis is concerned with assessing the worth of the service relative to the cost of providing it.

In terms of effectiveness, an ideal library application package should be able to perform and meet all expectations for which they are developed. In other words, application software should fulfill all systems expectations regarding their ability to perform library house keeping functions.

\section{Problem Statement}

At the commencement of the automation of their operations in the early seventies, Nigerian academic libraries were beset with a myriad of problems such as huge cost, lack of technical skills by library personnel, epileptic electricity power supply and other such problems that discouraged them from fully embracing automation fully. Over the years however, with the realization of the immense benefits and the abundant opportunities and possibilities offered by automation, Nigerian academic libraries had no options than to key into the automation race. Thus, the issue was not about whether or not they would, but when to embrace automation. Attention has now further shifted from when to embrace automation to how far the libraries have gone in the race.

There is no denying the fact that one of the most crucial decisions in library automation pertains to the type of library application software package to adopt. The choice of appropriate application package will go a long in ensuring the successes of the entire project. The Nigerian computer market place is saturated with a plethora of application packages most of which claim to be suitable for academic library automation. It is therefore necessary to assess the effectiveness of these packages in other to determine their suitability for library automation.

\section{Scope of the Study}

The study assessed the application packages adopted in the automation of six (6) academic libraries in Nigeria that are known to have made tremendous progress in the automation race. The assessment of the effectiveness of library application packages has been limited to software's security, compartibity/capabilities, userfriendliness. Indexing and searching abilities and other such features considered necessary in determining of an ideal library application software package. 


\section{Methodology Adopted}

The survey research method was adopted for the study. The data were collected using questionnaire. A Fifty-three (53) items structured questionnaire which had either a 2 or 3 point scale of Good, Fair, Poor, True or False or YES or NO was administered on the libraries under investigation. The respondents were asked to indicate one of the three or two options which best expresses their assessment of a particular point of view. The research instrument was divided into

Table 1:SYSTEM SECURITY PROCESS

\begin{tabular}{|c|c|c|c|c|c|c|c|c|c|c|c|c|}
\hline \multirow[t]{2}{*}{$\begin{array}{l}\text { SYSTEM SECURITY } \\
\text { PROCESS }\end{array}$} & \multicolumn{2}{|c|}{$\begin{array}{l}\text { A.B.U. } \\
\text { LIBRARY } \\
\text { ALICE FOR } \\
\text { WINDOWS } \\
5.502004\end{array}$} & \multicolumn{2}{|c|}{$\begin{array}{l}\text { UNILAG } \\
\text { LIBRARY } \\
\text { GLAS } 2004\end{array}$} & \multicolumn{2}{|c|}{$\begin{array}{l}\text { UNIJOS ITS } \\
2002\end{array}$} & \multicolumn{2}{|c|}{$\begin{array}{l}\text { U. I. ALICE } \\
\text { FOR } \\
\text { WINDOWS } \\
6.02004\end{array}$} & \multicolumn{2}{|c|}{$\begin{array}{l}\text { UNAAB } \\
\text { GLAS } 2001\end{array}$} & \multicolumn{2}{|c|}{$\begin{array}{l}\text { LASU ALICE } \\
\text { FOR } \\
\text { WINDOWS } \\
5.502004\end{array}$} \\
\hline & YES & $\mathrm{NO}$ & YES & $\mathrm{NO}$ & YES & $\mathrm{NO}$ & YES & $\mathrm{NO}$ & YES & $\mathrm{NO}$ & YES & $\mathrm{NO}$ \\
\hline $\begin{array}{l}\text { The software allow users } \\
\text { to define passwords and } \\
\text { their range of access to } \\
\text { the database. }\end{array}$ & $\sqrt{ }$ & - & $\sqrt{ }$ & - & $\sqrt{ }$ & - & $\sqrt{ }$ & - & $\sqrt{ }$ & - & $\sqrt{ }$ & - \\
\hline $\begin{array}{l}\text { The software protect data } \\
\text { from unintentional or } \\
\text { deliberate damage. }\end{array}$ & $\sqrt{ }$ & - & - & $\sqrt{ }$ & $\sqrt{ }$ & - & - & $\sqrt{ }$ & - & $\sqrt{ }$ & $\sqrt{ }$ & - \\
\hline $\begin{array}{l}\text { The software allows } \\
\text { program data back-up } \\
\text { while users are on the } \\
\text { system. }\end{array}$ & $\sqrt{ }$ & - & $\sqrt{ }$ & - & $\sqrt{ }$ & - & - & $\sqrt{ }$ & $\sqrt{ }$ & - & $\sqrt{ }$ & - \\
\hline $\begin{array}{l}\text { The software allows for } \\
\text { prompt recovery of data } \\
\text { after a disaster. }\end{array}$ & $\sqrt{ }$ & - & - & - & $\sqrt{ }$ & - & - & $\sqrt{ }$ & $\sqrt{ }$ & - & $\sqrt{ }$ & - \\
\hline $\begin{array}{l}\text { The software requires } \\
\text { passwords to particular } \\
\text { modules. }\end{array}$ & $\sqrt{ }$ & - & $\sqrt{ }$ & - & - & $\sqrt{ }$ & - & $\sqrt{ }$ & - & $\sqrt{ }$ & $\sqrt{ }$ & - \\
\hline $\begin{array}{l}\text { The software contains a } \\
\text { multi layered security } \\
\text { feature with passwords } \\
\text { that allows users/staff to } \\
\text { change password. }\end{array}$ & - & - & - & $\sqrt{ }$ & $\sqrt{ }$ & - & - & $\sqrt{ }$ & $\sqrt{ }$ & - & $\sqrt{ }$ & - \\
\hline $\begin{array}{l}\text { The software allows data } \\
\text { back-up and Restoration } \\
\text { of database file in case of } \\
\text { a disaster. }\end{array}$ & - & - & - & - & $\sqrt{ }$ & - & - & $\sqrt{ }$ & $\sqrt{ }$ & - & $\sqrt{ }$ & - \\
\hline $\begin{array}{l}\text { The software prevents } \\
\text { unauthorized access to } \\
\text { data. }\end{array}$ & $\sqrt{ }$ & - & $\sqrt{ }$ & - & - & - & $\sqrt{ }$ & - & $\sqrt{ }$ & - & $\sqrt{ }$ & - \\
\hline $\begin{array}{l}\text { The software allows for } \\
\text { printing of barcodes on } \\
\text { demand, combination of } \\
\text { barcodes with call } \\
\text { number and spine labels. }\end{array}$ & $\sqrt{ }$ & - & $\sqrt{ }$ & - & $\sqrt{ }$ & - & - & $\sqrt{ }$ & $\sqrt{ }$ & - & $\sqrt{ }$ & - \\
\hline
\end{tabular}

Note: $\sqrt{ }$ Denotes ability of application package to perform required operations. four sections numbered A-D. section A sought general background information on the libraries under investigation. Section B elicited information on whether or not their libraries were automated and their level of automation either full or partial. Section $\mathrm{C}$ focused on the type of library application packages adopted and their effectiveness, while section D sought general comments on the overall performance of adopted packages 
Findings and Discussion

Rowley (1990), Harbor (1994) and Meghabhab (1997) amongst several writers advised libraries embarking on automation projects to list the tasks the system is expected to perform and also to include essential specifications for all modules desired in the system both now and in the near future. The responding libraries were required to respond appropriately on their applications performance. Their responses have been analyzed and presented in tables $1-4$ below:

Table 2: SOFTWARE CAPABILITIES/COMPATIBILITY

\begin{tabular}{|c|c|c|c|c|c|c|c|c|c|c|c|c|}
\hline \multirow[t]{2}{*}{$\begin{array}{l}\text { SOFTWARE CAPABILITIES/ } \\
\text { COMPARTIBILITY }\end{array}$} & \multicolumn{2}{|c|}{$\begin{array}{l}\text { A.B.U. } \\
\text { LIBRARY } \\
\text { ALICE FOR } \\
\text { WINDOWS } \\
5.502004\end{array}$} & \multicolumn{2}{|c|}{$\begin{array}{l}\text { UNILAG } \\
\text { LIBRARY } \\
\text { GLAS 2004 }\end{array}$} & \multicolumn{2}{|c|}{$\begin{array}{l}\text { UNIJOS } \\
\text { ITS } 2002\end{array}$} & \multicolumn{2}{|c|}{$\begin{array}{l}\text { U. I. ALICE } \\
\text { FOR } \\
\text { WINDOWS } \\
6.02004\end{array}$} & \multicolumn{2}{|c|}{$\begin{array}{l}\text { UNAAB } \\
\text { GLAS } 2001\end{array}$} & \multicolumn{2}{|c|}{$\begin{array}{l}\text { LASU } \\
\text { ALICE } \\
\text { FOR } \\
\text { WINDOWS } \\
5.502004\end{array}$} \\
\hline & YES & NO & YES & NO & YES & NO & YES & NO & YES & NO & YES & NO \\
\hline $\begin{array}{l}\text { The software is MARC and on- } \\
\text { MARC complaint }\end{array}$ & $\sqrt{ }$ & - & $\sqrt{ }$ & - & $\sqrt{ }$ & - & $\sqrt{ }$ & - & $\sqrt{ }$ & - & $\sqrt{ }$ & - \\
\hline $\begin{array}{l}\text { The software accommodates } \\
\text { simultaneous multi-user access }\end{array}$ & $\sqrt{ }$ & - & $\sqrt{ }$ & - & $\sqrt{ }$ & - & $\sqrt{ }$ & - & $\sqrt{ }$ & - & $\sqrt{ }$ & - \\
\hline $\begin{array}{l}\text { The software allows the various } \\
\text { modules to share one bibliographic } \\
\text { database. }\end{array}$ & $\sqrt{ }$ & - & $\sqrt{ }$ & - & $\sqrt{ }$ & - & $\sqrt{ }$ & - & $\sqrt{ }$ & - & $\sqrt{ }$ & - \\
\hline The software is web-compatible & $\sqrt{ }$ & - & $\sqrt{ }$ & - & $\sqrt{ }$ & - & $\sqrt{ }$ & - & $\sqrt{ }$ & - & $\sqrt{ }$ & - \\
\hline $\begin{array}{l}\text { The software allows for internet } \\
\text { access. }\end{array}$ & $\sqrt{ }$ & - & - & $\sqrt{ }$ & $\sqrt{ }$ & - & $\sqrt{ }$ & - & $\sqrt{ }$ & - & $\sqrt{ }$ & - \\
\hline $\begin{array}{l}\text { The software is network able and } \\
\text { compatible with Novell Netware to } \\
\text { support a Local Area Network } \\
\text { (LAN) }\end{array}$ & $\sqrt{ }$ & - & $\sqrt{ }$ & - & $\sqrt{ }$ & - & $\sqrt{ }$ & - & $\sqrt{ }$ & - & $\sqrt{ }$ & - \\
\hline The software is intranet compatible & $\sqrt{ }$ & - & $\sqrt{ }$ & - & $\sqrt{ }$ & - & $\sqrt{ }$ & - & $\sqrt{ }$ & - & $\sqrt{ }$ & - \\
\hline $\begin{array}{l}\text { The software allows for the } \\
\text { expansion of the integrated multiple } \\
\text { modules. }\end{array}$ & - & - & $\sqrt{ }$ & - & $\sqrt{ }$ & - & $\sqrt{ }$ & - & $\sqrt{ }$ & - & $\sqrt{ }$ & - \\
\hline $\begin{array}{l}\text { The software allows for digitization } \\
\text { of data/resources }\end{array}$ & $\sqrt{ }$ & - & $\sqrt{ }$ & - & - & - & & - & & - & & - \\
\hline $\begin{array}{l}\text { The software allows for the } \\
\text { generation of a variety of statistics } \\
\text { and other reports and allow staff to } \\
\text { customize reports }\end{array}$ & - & - & $\sqrt{ }$ & - & $\sqrt{ }$ & - & $\sqrt{ }$ & - & $\sqrt{ }$ & - & $\sqrt{ }$ & - \\
\hline $\begin{array}{l}\text { The software supports } \\
\text { Telecommunication for simultaneous } \\
\text { and remote dial-up access for users. }\end{array}$ & - & - & - & $\sqrt{ }$ & - & $\sqrt{ }$ & - & $\sqrt{ }$ & $\sqrt{ }$ & - & $\sqrt{ }$ & - \\
\hline $\begin{array}{l}\text { The software is in full compliance } \\
\text { with the Z39.50 standard. }\end{array}$ & $\sqrt{ }$ & - & $\sqrt{ }$ & - & $\sqrt{ }$ & - & $\sqrt{ }$ & - & $\sqrt{ }$ & - & $\sqrt{ }$ & - \\
\hline
\end{tabular}


Table 3:INDEXING AND SEARCHING ABILITIES OF SOFTWARE

\begin{tabular}{|c|c|c|c|c|c|c|c|c|c|c|c|c|}
\hline \multirow[t]{2}{*}{$\begin{array}{l}\text { INDEXING AND } \\
\text { SEARCHING } \\
\text { ABILITIES OF } \\
\text { SOFTWARE }\end{array}$} & \multicolumn{2}{|c|}{$\begin{array}{l}\text { A.B.U. } \\
\text { LIBRARY } \\
\text { ALICE FOR } \\
\text { WINDOWS } \\
5.502004\end{array}$} & \multicolumn{2}{|c|}{$\begin{array}{l}\text { UNILAG } \\
\text { LIBRARY } \\
\text { GLAS } 2004\end{array}$} & \multicolumn{2}{|c|}{$\begin{array}{l}\text { UNIJOS ITS } \\
2002\end{array}$} & \multicolumn{2}{|c|}{$\begin{array}{l}\text { U. I. ALICE } \\
\text { FOR } \\
\text { WINDOWS } \\
6.02004\end{array}$} & \multicolumn{2}{|c|}{$\begin{array}{l}\text { UNAAB } \\
\text { GLAS } 2001\end{array}$} & \multicolumn{2}{|c|}{$\begin{array}{l}\text { LASU ALICE } \\
\text { FOR } \\
\text { WINDOWS } \\
5.502004\end{array}$} \\
\hline & YES & NO & YES & NO & YES & NO & YES & NO & YES & NO & YES & NO \\
\hline $\begin{array}{l}\text { Alphabetical searches } \\
\text { of selected index }\end{array}$ & $\sqrt{ }$ & - & $\sqrt{ }$ & - & $\sqrt{ }$ & - & $\sqrt{ }$ & - & $\sqrt{ }$ & - & $\sqrt{ }$ & - \\
\hline $\begin{array}{l}\text { Boolean searches } \\
\text { which use such words } \\
\text { as And or and Not to } \\
\text { connect words. }\end{array}$ & $\sqrt{ }$ & - & $\sqrt{ }$ & - & $\sqrt{ }$ & - & $\sqrt{ }$ & - & $\sqrt{ }$ & - & $\sqrt{ }$ & - \\
\hline $\begin{array}{l}\text { Full text searching } \\
\text { which provides the } \\
\text { capability to search } \\
\text { and word appearing in } \\
\text { the database or in a } \\
\text { specified field of the } \\
\text { database. }\end{array}$ & - & - & $\sqrt{ }$ & - & - & - & $\sqrt{ }$ & - & $\sqrt{ }$ & - & $\sqrt{ }$ & - \\
\hline $\begin{array}{l}\text { Keyword searches that } \\
\text { allow users to scan } \\
\text { selected indexes for } \\
\text { specific words or } \\
\text { phases. }\end{array}$ & $\sqrt{ }$ & - & $\sqrt{ }$ & - & $\sqrt{ }$ & - & $\sqrt{ }$ & - & $\sqrt{ }$ & - & $\sqrt{ }$ & - \\
\hline $\begin{array}{l}\text { Proximity searches } \\
\text { that allow users to } \\
\text { specify how close } \\
\text { keywords should be. }\end{array}$ & - & - & $\sqrt{ }$ & - & - & - & - & - & $\sqrt{ }$ & - & $\sqrt{ }$ & - \\
\hline $\begin{array}{l}\text { Wildcard searches } \\
\text { with the use of } \\
\text { asterisks and question } \\
\text { marks to indicate } \\
\text { unknown characters or } \\
\text { a known quality of } \\
\text { unknown characters. }\end{array}$ & - & - & - & - & - & - & - & - & $\sqrt{ }$ & - & - & - \\
\hline
\end{tabular}


Table 4:USER-FRIENDLINESS OF LIBRARY APPLICATION SOFTWARES

\begin{tabular}{|c|c|c|c|c|c|c|c|c|c|c|c|c|}
\hline \multirow[t]{2}{*}{ FEATURES } & \multicolumn{2}{|c|}{$\begin{array}{l}\text { A.B.U. } \\
\text { LIBRARY } \\
\text { ALICE FOR } \\
\text { WINDOWS } \\
5.502004\end{array}$} & \multicolumn{2}{|c|}{$\begin{array}{l}\text { UNILAG } \\
\text { LIBRARY } \\
\text { GLAS } 2004\end{array}$} & \multicolumn{2}{|c|}{$\begin{array}{l}\text { UNIJOS ITS } \\
2002\end{array}$} & \multicolumn{2}{|c|}{$\begin{array}{l}\text { U. I. ALICE } \\
\text { FOR WINDOW } \\
\text { S.600 } 2004\end{array}$} & \multicolumn{2}{|c|}{$\begin{array}{l}\text { UNAAB GLAS } \\
2001\end{array}$} & \multicolumn{2}{|c|}{$\begin{array}{l}\text { LASU ALICE } \\
\text { FOR } \\
\text { WINDOWS } 5.50 \\
2004\end{array}$} \\
\hline & $\begin{array}{l}\text { Tru } \\
\mathrm{e}\end{array}$ & False & True & False & True & False & True & False & True & False & True & False \\
\hline $\begin{array}{l}\text { The Library } \\
\text { application } \\
\text { software is menu } \\
\text { driven }\end{array}$ & $\sqrt{ }$ & - & $\sqrt{ }$ & - & $\sqrt{ }$ & - & $\sqrt{ }$ & - & $\sqrt{ }$ & - & $\sqrt{ }$ & - \\
\hline $\begin{array}{l}\text { The Library } \\
\text { application is } \\
\text { command driven }\end{array}$ & - & $\sqrt{ }$ & - & $\sqrt{ }$ & - & - & - & $\sqrt{ }$ & - & $\sqrt{ }$ & - & $\sqrt{ }$ \\
\hline $\begin{array}{l}\text { The software allow } \\
\text { users to navigate } \\
\text { particular areas on } \\
\text { the screen }\end{array}$ & $\sqrt{ }$ & - & $\sqrt{ }$ & - & $\sqrt{ }$ & - & $\sqrt{ }$ & - & $\sqrt{ }$ & - & $\sqrt{ }$ & - \\
\hline $\begin{array}{l}\text { The software } \\
\text { allows modules to } \\
\text { interface and to } \\
\text { work both } \\
\text { independently of } \\
\text { and concurrently } \\
\text { with each other }\end{array}$ & $\sqrt{ }$ & - & $\sqrt{ }$ & - & $\sqrt{ }$ & - & $\sqrt{ }$ & - & $\sqrt{ }$ & - & $\sqrt{ }$ & - \\
\hline $\begin{array}{l}\text { The software } \\
\text { maintains clear } \\
\text { well-written well } \\
\text { organized and easy } \\
\text { to use } \\
\text { documentation }\end{array}$ & $\sqrt{ }$ & - & $\sqrt{ }$ & - & $\sqrt{ }$ & - & $\sqrt{ }$ & - & $\sqrt{ }$ & - & $\sqrt{ }$ & - \\
\hline $\begin{array}{l}\text { The software } \\
\text { explains the } \\
\text { operation of the } \\
\text { entire system. It } \\
\text { also provides } \\
\text { instructions with } \\
\text { examples for each } \\
\text { module }\end{array}$ & $\sqrt{ }$ & - & $\sqrt{ }$ & - & - & - & $\sqrt{ }$ & - & $\sqrt{ }$ & - & $\sqrt{ }$ & - \\
\hline $\begin{array}{l}\text { The adopted } \\
\text { software is easy to } \\
\text { maintain }\end{array}$ & $\sqrt{ }$ & - & - & $\sqrt{ }$ & $\sqrt{ }$ & - & $\sqrt{ }$ & - & $\sqrt{ }$ & - & $\sqrt{ }$ & - \\
\hline
\end{tabular}


Table 1 above suggests that most of the adopted software packages do not only protect data against unauthorized access but they are also able to withstand interference with system operations. The presence of appropriate security mechanism implies protection in the face of malicious, intelligent and adoptive attackers.

On software compatibility and indexing searching abilities depicted in tables 2 and 3, the responses of the libraries studied indicate the capability of most adopted packages to perform most library operations including those not presently undertaken by the libraries. This implies that Nigerian academic libraries, most especially, those under investigation are yet to fully tap the benefits of library automation.

The preponderance of opinions amongst the libraries studied suggests that most application software packages adopted are user-friendly as shown in Table 4

The libraries agreed that their adopted packages are easily operated and well on multiple computer configurations. They are convenient and practicable to use through the Graphical user interface. This has no doubt improved the range of access of library patrons to information.

\section{Conclusion}

As the fulcrum that propels other processes, the effectiveness of library application software packages to a significant extent determines the overall direction of the automation project. In the light of the findings and discussion in the foregoing, the study concludes that most library application software packages on Management. available in the Nigerian computer marketplaces are packages that have been fully tested, thoroughly debugged and well-supported by vendors and are suitable for library automation most especially in academic libraries.

\section{References}

Rowley J. (1995) The Basics of Systems Analysis and Design for Information Managers. London: Clive Bingley.

Aiyedogbon C. E. (1997) Factors influencing the levels of library automation in Selected research institutes in Nigeria. Unpublished MLS Thesis Ahmadu Bello University Zaria

Bierman P. (1980) Library automation ARIJI vol. 9. In Technology for Information management and science (ed) madu E. C. Ibadan: Evi-coleman P.3

Meghabghab D. B. (1997) Automating media centres and small libraries: A Micro-computer-based approach Eaglewood: Libraries unlimited, Inc. P.5-6.

Mohammed Z. (1999) "Automating and Internetting Nigerian Libraries and Information centres: obstacles, prospects and strategies" Lagos Librarian $20(1 \& 2)$.

Harbour, R. T. (1994) Managing library Automation: An Aslib Know How Guide. London: Aslib, The Association for Information 